\title{
Teologi Pembebasan Beragama dalam Film Bollywood
}

\author{
Maria Ulfa ${ }^{1 *}$, Bambang Qomaruzzaman, ${ }^{2}$ dan Abdul Syukur ${ }^{3}$ \\ 1 Al-Washliyah Aceh, Indonesia; mariaulfa.ney@gmail.com \\ 2 UIN Sunan Gunung Djati Bandung, Indonesia; bambang.q.anees@uinsgd.ac.id \\ 3 UIN Sunan Gunung Djati Bandung, Indonesia; asyukur217@gmail.com \\ * Correspondence
}

Received: 2021-01-21; Accepted: 2021-04-27; Published: 2021-04-30

\begin{abstract}
Liberation theology does not only take the form of teaching, organization, and so on. Lately, liberation theology is into a film, such as the Bollywood film PEEKEY and OH MY GOD. With these two films, the researchers want to see religious issues raised in Bollywood films, especially issues of religious liberation. This research is qualitative research using the method of analysis model Roland Barthes. The analysis results in this study reveal that the PK and OMG films have provided an overview of religious issues that are no longer relevant to the actual goals of religion. Then this Bollywood film liberates God from the wrong understanding of God, frees people from enmity because of belief, and frees people from poverty and oppression of religious elites. This study is a typical analysis of religious philosophy, which can revive people's creativity by discussing religious issues.
\end{abstract}

Keywords: Religious Issues, Liberation Theology, Roland Barthes, comedy films.

Abstrak: Teologi pembebasan tidak hanya berbentuk ajaran, organisasi, dan sebagainya. Akhir-akhir ini teologi pembebasan juga dituangkan melalui sebuah film, seperti film Bollywood PEEKEY dan OH MY GOD. Dengan kedua film tersebut, peneliti ingin melihat isu-isu agama yang diangkat dalam film Bollywood, terutama isyu pembebasan agama. Penelitian ini merupakan penelitian kualitatif dengan menggunakan metode analisis model Roland Barthes. Hasil analisis pada pada penelitian ini mengungkapkan bahwa film PK dan OMG telah memberikan gambaran isu agama yang tidak lagi relevan dengan tujuan agama yang sebenarnya. Kemudian film Bollywood ini melakukan pembebasan Tuhan dari pemahaman Tuhan yang salah, kemudian membebaskan manusia dari permusuhan karena agama dan yang ketika membebaskan manusia dari kemiskinan dan ketertindasan elit agama. Kajian ini merupakan analisis khas ala filsafat agama, yang dapat menghidupkan kreativitas masyarakat melalui pembahasan isyu-isyu keagamaan.

Kata Kunci: Isu Agama, Teologi pembebasan, Roland Barthes, film komedi.

\section{Pendahuluan}

Riset ini akan mengangkat tentang pesan pembebasan umat beragama dari ketertindasan, yang terdapat dalam pesan film Bollywood yang berjudul PEEKEY dan OH MY GOD. Kedua film Bollywood ini merupakan film komedi yang berbau religi, yang menggambarkan kebebasan diri dari ketertindasan yang dilakukan oleh elit agama, yang memanfaatkan agama demi kepentingan dirinya sediri.

Istilah teologi pembebasan pertama kali muncul dalam tradisi Kristen. Teologi pembebasan merupakan bagian dari seruan agama untuk membela keadilan dan kesejahteraan umat manusia (Nitiprawiro, 2000). Selain itu teologi pembebasan merupakan salah satu usaha kontekstualisasi ajaranajaran dan nilai keagamaan pada masalah konkret di sekitarnya (wikipedia, 2020). Jadi teologi 
pembebasan muncul sebagai respon terhadap situasi politik dan ekonomi yang terbilang dapat menyiksa umat beragama.

Film memang merupakan hal yang biasa saja dan tidak penting. Namun film merupakan salah satu media sosial, yang bisa membawa banyak pengaruh positif dan bisa juga berdampak negative (Willya, 2012). Sehingga tidak heran bahwa film juga memiliki pengaruh besar dalam kehidupan masyarakat. Film mampu membangkitkan emosional atau proses yang hampir tidak terkontrol oleh setiap individu. Terkadang film dapat menuai kontroversi, atau dapat menjadi bahan pembelajaran.

Melihat ke realita saat ini, banyak ditemui berbagai pemasalahan sosial, seperti kemiskinan, kebodohan, ketertindasan dan berbagai macam permasalahan sosial lainnya. Akhir-akhir ini berkembang isu agama adalah masalah bagi manusia, misalnya agama Islam diklaim sebagai agama yang mengajarkan kekerasan dan bias gender, Agama Hindu mendiskriminasikan kasta. Degan demikian film PEEKEY dan OH MY GOD ini mencoba memberikan pesan yang membangun agar masyarakat terbebas dari masalah sosial tersebut. Berdasarkan dari latar belakang di atas, penelitian ini akan mengkaji isi dari pesan film PK dan OMG, dalam membebaskan dan memerdekakan umat beragama dari elit agama yang memanfaatkan agama untuk kepentingan pribadi.

Film PK dan OMG merupakan film komedi yang bernuansa religi, dalam kedua film tersebut mengandung pesan yang hendak disampaikan kepada khalayak. Pesan yang disampaikan tentu sangat bervariasi, sesuai latar belakang di atas, penulis akan merumuskan masalah sebagai berikut: 1. Bagaimanakah gambaran isu-isu sosial agama dalam film Bollywood tersebut?

2. Bagaimanakah strategi teologi pembebasan agama yang terdapat dalam film Bollywood tersebut?

Film adalah salah satu media yang sangat relevan dalam penyampaian pesan ke khalayak ramai. Undang-undang Nomor 33 Tahun 2009 tentang Perfilman pada Bab I Pasal 1 menyebutkan, yang dimaksud dengan film adalah karya seni budaya, yang merupakan prananta sosial dan media komunikasi massa yang dibuat berdasarkan kaidah sinematografi dengan atau tanpa suara dan dapat dipertunjukan (Vera, 2014). Film merupakan salah satu media komunikasi massa, karena merupakan bentuk komunikasi yang menggunakan saluran (media) dalam menghubungkan komunikator dan komunikan secara massal dalam arti melibatkan orang banyak dan media juga dapat menimbulkan efek positif dan negative (Vera, 2014).

Kritik terhadap sastra pertama kali dilakukan oleh orang Yunani bernama Xenophane dan Heraclitus pada tahun 500 SM, dengan mengecam Homerus, yang sering mengisahkan cerita bohong dan tidak senonoh tentang dewa-dewi (Yudiono, 2009). Berbicara masalah kritik, kritik berasal dari bahasa Yunani yaitu krites yang berarti memisahkan atau memerinci (Kwant, 1975). Menurut Astrid S.Susanto, kritik sosial biasanya dihubungkan dengan perlunya suatu situasi yang ideal serta prilaku yang ideal (Susanto, 1977). Dalam kritikan selalu menginginkan suatu perubahan, selain itu kritik juga selalu berorientasi pada arah masa depan. Oleh karena itu dalam kritikan sangat diperlukan data dan pengetahuan yang akurat dan tepat, supaya prediksi suatu masalah dalam masyarakat menjadi tepat.

Dalam tantangan modernitas, agama dihadapkan pada tuntutan kehidupan manusia. Tuntutan kehidupan tersebut pada realita empirik yang memprihatinkan, seperti, ketertindasan, kebodohan, kemiskinan, korupsi, imprialisme budaya dan problematika lainnya. Semua problematika tersebut menegaskan bahwa, agama belum bisa menjadi solusi dalam kehidupan manusia saat ini. Seolah-olah agama memiliki wajah mendua, yang mengandung ambiguitas, di mana agama pada satu sisi menghasilkan nilai-nilai humanistis dan spirit pembebasan. Namun di sisi lain, agama memperlihatkan arogansi dan otoritarianisme yang membelenggu dan membebani penganutnya (Ridwan, 2016).

Melihat realitas sekarang, agama telah menjadi penyebab ketidak-mampuan manusia menghadapi kehidupannya. Kenyataan ini merupakan bentuk refleksi atas kegagalan peran agama, karena agama terlalu bersifat dogmatis, kurang mencerminkan pemecahan masalah (problem solving) sebagaimana diharapkan oleh masyarakat. Sehingga agamalah sebagai pusat kritik atas problematika kehidupan masyarakat saat ini.

Dewasa ini agama menjadi isu yang menarik untuk direpresentasikan dalam film. Film merupakan media yang dianggap sebagai penemuan penting, karena dapat menghubungkan 
pemikiran manusia yang satu dengan manusia yang lain serta pesan yang disampaikan dapat diterima dengan baik (Aryanto, 2009). Pesan yang bersifat subyektif tidak jarang menimbulkan pro dan kontra terhadap pesan yang dibangun.

Semiotika berasal dari kata Yunani semeion yang berarti tanda. Semiotika adalah cabang ilmu yang berurusan dengan pengkajian tanda dan segala sesuatu yang berhubungan dengan tanda, seperti sistem tanda dan proses yang berlaku (Lantowa, Marahayu, \& Khairussibyan, 2017). Semiotika adalah intrumen pembuka rahasia teks dan penandaan, karena semiotika adalah puncak logis dari apa yang disebut Derrida sebagai "logosentrisme". Semiotika berawal dari kritikan atas asumsi logosentris yang konsep-konsepnya muncul mendahului dan bebas dari ekspresinya (Kurniawan, 2001). Pada mulanya konsep semiotik diperkenalkan oleh Ferdinand de Saussure melalui sistem tanda signiefied dan signifier dan significat yang bersifat atomistis (Tazid, 2017).

Roland Barthes adalah salah satu yang meneruskan pemikiran Saussure. Walaupun demikian, bagi Barthes suatu tanda tidaklah sesimpel yang dikemukakan Saussure melainkan suatu tanda akan diperoleh makna melalui kolaborasi teks dan pegalaman penggunanya. Semiotika Barthes dalam memperoleh makna dari suatu tanda mencakup denotasi dan konotasi. Denotasi merupakan makna sebenarnya sesuai kamus, sedangkan konotasi makna tambahan yang lahir dari pengalaman kultural atau personal. Selain kedua hal tersebut Barthes menggunakan aspek penandaan dengan mitos (Tazid, 2017).

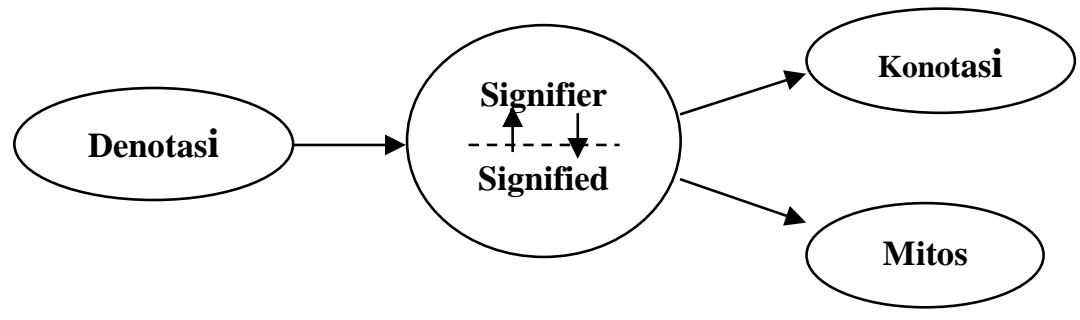

Perspektif Barthes tentang mitos menjadi salah satu ciri khas semiologinya, yang mana dengan mitos penggalian akan lebih jauh dari penandaan, untuk mencapai mitos yang berkerja di dalam realitas kehidupan masyarakat (Kurniawan, 2001). Mitos dalam aliran Barthes, bukanlah mitos seperti kisah mitologi atau sejenisnya. Mitos di sini adalah ideologi, Gagasan yang terus diproduksi di mana tanda berada (Narodangin, 2019). Barthes mengemukakan mitos adalah bahasa, maka mitos adalah sebuah sistem komunikasi dan mitos adalah sebuah pesan. Dalam uraiannya, Barthes mengemukakan bahwa mitos dalam pengertian khusus ini merupakan perkembangan dari konotasi.

Teologi pembebasan merupakan istilah yang menggambarkan fenomena pada aspek teologi, yang kemudian melahirkan banyak pemikir yang menuntut supaya teologi tidak lagi menjadikan ajaranya sebagai sebuah kendaraan untuk menindas penganutnya. Selain itu teologi pembebasan merupakan salah satu usaha kontektualisasi ajaran-ajaran dan nilai keagamaan pada masalah konkret di sekitarnya (wikipedia, 2020).

Pembebasan menurut Boff (1974) adalah sebuah proses menuju kemerdekaan (Nitiprawiro, 2010). Pembebasan dari segala sistem penindasan, untuk keperluan dirinya sendiri baik dalam politik, ekonimi dan kultural. Gutierrez kemudian mendefinisikan teologi sebagai "critical reflection on praxis in the light of God's word." Ada tiga aspek yang terkandung dalam teologi pembebasan Amerika Latin (Nitiprawiro, 2010). Pertama, Pembebasan dari belenggu penindasan ekonomi, sosial dan politik atau alienasi kultural serta kemiskinan dan ketidak-adilan. Kedua, pembebasan dari kekerasan yang melembaga. Ketiga, pembebasan dari dosa yang memungkinkan manusia masuk dalam persekutuan dengan Tuhan dan semua manusia.

Teologi pembebasan berbeda dengan liberalism, karena liberalism mendukung akan segala sesuatu yang merujuk pada kebebasan, seperti bebas berpendapat, bebas memilih apa pun untuk kehidupannya, bahkan bebas beragama atau meyakini apa pun yang menurutnya benar. Sedangkan Teologi pembebasan merupakan bagian dari seruan agama, untuk membela keadilan dan kesejahteraan umat manusia (Nitiprawiro, 2010). Selain itu teologi pembebasan merupakan salah satu 
usaha kontektualisasi ajaran-ajaran dan nilai keagamaan pada masalah konkret di sekitarnya (wikipedia, 2020). Jadi teologi pembebasan muncul sebagai respon terhadap situasi politik dan ekonomi yang terbilang dapat menyiksa umat beragama.

\section{Metodologi Penelitian}

Metode penelitian yang akan penulis gunakan adalah metode penelitian kualitatif analisis. Menurut Bogdan dan Taylor sebagaimana dikutip oleh Moleong metode kualitatif adalah prosedur penelitian yang menghasilkan data deskriptif berupa kata-kata atau lisan dari orang-orang dan perilaku yang dapat diamati (Moleong, 2019).

Analisis yang digunakan dalam penelitian ini, peneliti akan menggunakan analisis semiotika model Roland Barthes. Dalam analisis semiotik menggunakan sistem tanda signiefied dan signifier yang kemudia Barthes menyebutnya sebagai denotasi. Makna yang dihasilkan dari denotasi bagi Barthes akan menimbulkan makna yang kedua yang disebut dengan konotasi.

Konotasi yang sudah terbentuk lama di masyarakat itulah mitos, yang kemudian mitos inilah yang menjadi ciri khas semiotika Barthes. Barthes juga mengatakan bahwa mitos merupakan sistem semiologis, yakni sistem tanda-tanda yang dimaknai manusia (Hoed, 2008). Mitos dapat dikatakan sebagai produk kelas sosial yang sudah memiliki suatu dominasi. Mitos Barthes dengan sendirinya berbeda dengan mitos yang kita anggap tahayul, tidak masuk akal, ahistoris, dan lain-lain, tetapi mitos menurut Barthes sebagai type of speech (gaya bicara) seseorang (Vera, 2014).

Dengan demikian peneliti menggunkan analisis semiotik model Roland Barthes untuk menginterpretasikan makna-makna yang terkandung dalam film PEEKEY dan OH MY GOD, sebagai materi dan objek penelitian. Analisis ini secara umum berupaya mengungkapkan berbagai informasi atau pesan dibalik data yang disajikan di media, baik berupa gambar, kata, simbol, ide dan segala sesuatu yang dikomunikasikan.

\section{Gambaran Film PEEKEY dan OH MY GOD}

Film PK yang disutradarai Rajkumar Hirani ini dirilis pada tanggal 19 Desember 2014 dengan berdurasi 2 jam 32 menit. Film PK ini diperankan oleh Amir Khan (sebagai PK) dan Anushka Sharma (sebagai Jaggu) selaku pemeran utama dalam film ini. Film ini menggambarkan perjalanan sosok alien yang dikirim ke bumi untuk sebuah misi tertentu akan tetapi terjadi sebuah musibah yang menimpa alien tersebut, sehingga menyebabkan kehilangan benda berharganya. Alien tersebut pun mencari benda berharganya dengan meminta pertolongan kepada manusia, namun semua manusia berkata hanya Tuhan yang dapat menolongnya. PK akhirnya mulai mencari Tuhan dan mempelajari semua ajaran agama yang ada di India. Dalam pencariannya banyak sekali terdapat "wrong number" salah sambung dalam penyampaian ajaran dan bahkan menanamkan prasanga buruk kepada agama lainnya oleh elit agama.

Kedua, film OH MY GOD (OMG) dirilis tahun 2012 ini menggambarkan seseorang yang bernama Khanji, yang berasal dari kalangan masyarakat menengah yang sedang dilanda musibah. Khanji mendapat musibah gempa yang menghancurkan tokonya. Sebelumnya Khanji merupakan nasabah pada sebuah perusahaan asuransi, namun saat dilanda musibah, pihak asuransi menolak menggantikan kerugian Khanji dengan alasan musibah tersebut adalah "Act Of God" bukan manusia. Setelah kejadian tersebut akhirnya Khanji menggugat perbuatan Tuhan ke pengadilan, mengirimkan surat tuntutan ke semua tempat ibadah yang merupakan rumah Tuhan atau tempat semua umat manusia mencari Tuhan, namun pemuka agama juga menolak untuk mengganti rugi yang dialami Khanji.

Elit agama pada kedua film tersebut digambarkan sebagai wakil Tuhan atau managernya Tuhan. Dalam kehidupan beragama terdapat dua jenis manager Tuhan, pertama, orang yang menerima wahyu langsung dari Tuhan. Kedua, melanjutkan wahyu yang didapatkan oleh orang yang pertama. Dalam menyampaikan wahyu, tentu ada yang sifatnya manusiawi yang bisa salah dan ada yang sengaja memanfaatkan agama demi memuaskan nafsu. Sifat tokoh agama yang kedua ini yang dapat membuat 
tindakan semena-mena terhadap rakyat kecil, demi keuntungannya saja. Sehingga kedua film tersebut ingin membebaskan umat beragama dari sifat tokoh yang kedua tersebut.

\section{Isu-Isu Sosial dalam Film Bollywood}

\section{Isu Agama sebagai Sumber Kemiskinan}

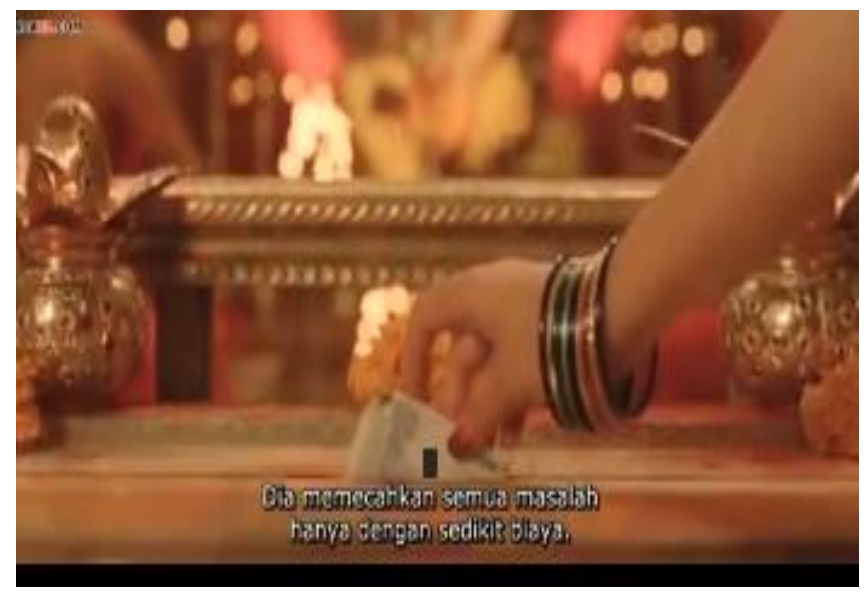

Gambar 1. Seseorang memasukkan uang ke sebuah kotak amal untuk memecahkan masalah

\begin{tabular}{llc}
\hline & $\begin{array}{c}\text { Penanda } \\
\text { Dia memecahkan semua masalah } \\
\text { hanya dengan sedikit biaya }\end{array}$ & $\begin{array}{c}\text { Petanda } \\
\text { Seseorang ingin memecahkan } \\
\text { masalah dengan memasukkan uang } \\
\text { ke kotak amal }\end{array}$ \\
\hline Denotasi & memecahkan semua masalah hanya dengan sedikit biaya \\
\hline Konotasi & Tuhan akan menyelesaikan masalah jika diberikan uang \\
\hline
\end{tabular}

Semua umat manusia, baik yang beragama Hindu, Islam, Kristen, Sikh dan agama lainnya. Apakah seseorang itu berprofesi polisi, pedagang, dan apakah itu laki-laki dan perempuan, muda dan tua, semuanya menaruh harapan kepada Tuhan, bahwa segala masalah yang dihadapi oleh manusia akan terselesaikan oleh Tuhan. Setiap umat manusia yang mempunyai masalah, rela melakukan berbagai bentuk ritual yang diminta dalam agama, termasuk memberikan uang.

Adanya Tuhan memang patut diyakini oleh manusia, bahwa Tuhanlah yang telah menciptakan manusia. Tuhan jugalah yang memberikan pertolongan dan imbalan atas ketaatan orang-orang dalam beribadah, namun hal tersebut telah disalahartikan sehingga berdampak pada pengaruh malasnya seseorang untuk berusaha dan mereka hanya berdoa terus-menerus dan hanya cenderung pasrah tanpa berusaha untuk keluar dari masalah mereka.

Agama menjadi tempat harapan bagi yang tidak mampu memecahkan masalah sosial disekelilingnya, dan agama sebagai tempat pelarian manusia yang lemah terhadap nasib yang menimpanya. Seperti yang dikatakan Karl Marx bahwa agama sebagai candu rakyat. Dalam hal ini agama dianggap mengabaikan usaha-usaha konkrit manusia untuk memperjuangkan taraf hidupnya (Suseno, 1999). 

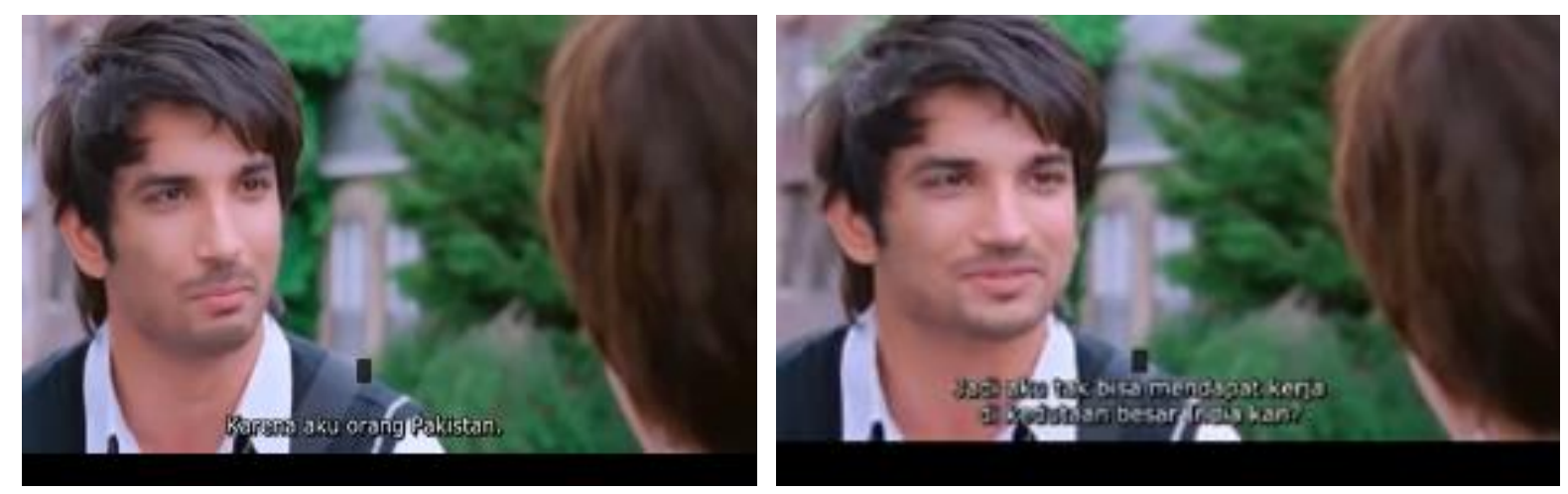

Gambar 2. Warga Pakistan dilarang bekerja di India

Sarfaraz :Mahasiswa Arsitek, yang bekerja paruh waktu di kedutaan Pakistan.

Jaggu :Kenapa di Pakistan?

Sarfaraz :Karena aku orang Pakistan, jadi aku tidak bisa mendapat kerja di kedutaan besar Indiakan?Kenapa?

Jaggu :tidak ada

Sarfaraz :Setelah bilang Pakistan, senyum mu menghilang.

\begin{tabular}{|c|c|c|}
\hline & Penanda & Petanda \\
\hline Denotasi & $\begin{array}{l}\text { "karena aku orang Pakistan jadi tak bisa } \\
\text { mendapat kerja di Kedutaan besar Indiakan?" }\end{array}$ & $\begin{array}{l}\text { Tidak dapat bekerja di } \\
\text { kedutaan Pakistan }\end{array}$ \\
\hline Konotasi & $\begin{array}{l}\text { Pn } 2 \\
\text { Orang Pakistan tidak bisa bekerja di India }\end{array}$ & \\
\hline Mitos & $\begin{array}{l}\text { Pn3 } \\
\text { Orang Pakistan dilarang bekerja di India }\end{array}$ & \\
\hline
\end{tabular}

Potongan gambar 2 merepresentasikan realita bahwa adanya agama yang beragam menimbulkan konflik antar agama. Setiap agama mengajarkan perdamaian, namun faktanya agama terkadang justru menjadi salah satu faktor terjadinya konflik. Terjadinya konflik antar agama seolah-olah menggambarkan wajah keagamaan dari sisi yang berbeda, yang satu mengajarkan kasih dan sayang, yang lain benci dan dendam.

Meskipun setiap agama mengajarkan perdamaian, kebersamaan sekaligus menebar misi kemaslahatan bagi lingkungan disekitarnya. Namun dalam tataran sosiologis (Wibisono, 2020), wajah agama tidak seideal seperti yang diharapkan dalam kerangka normatif tersebut. Kerap kali wajah agama tampak tercoreng dan ternoda dalam konflik sosial, budaya, dan politik. Demikian itu sebenarnya bukan kesalahan ajaran agama itu sendiri, namun lebih diakibatkan human error, yakni sikap sebagian para pemeluknya.

Sebagaimana pada scene di atas menujukkan seorang yag berlatar belakang muslim dan pakistan tidak diperbolehkan bekerja di India yang berlatar agama Hindu, bagi orang India muslim adalah teroris. Hal ini disebabkan oleh sejarah ketegangan antara Hindu-Islam pada tahun 1947 terhadap peroalan perebutan negara Kashmir adalah miliknya. Sehingga dalam film PEEKEY mengangkan isu sosial keagamaan berkaitan rusaknya hubungan antar umat beragama di India (Rahman, 2018). 

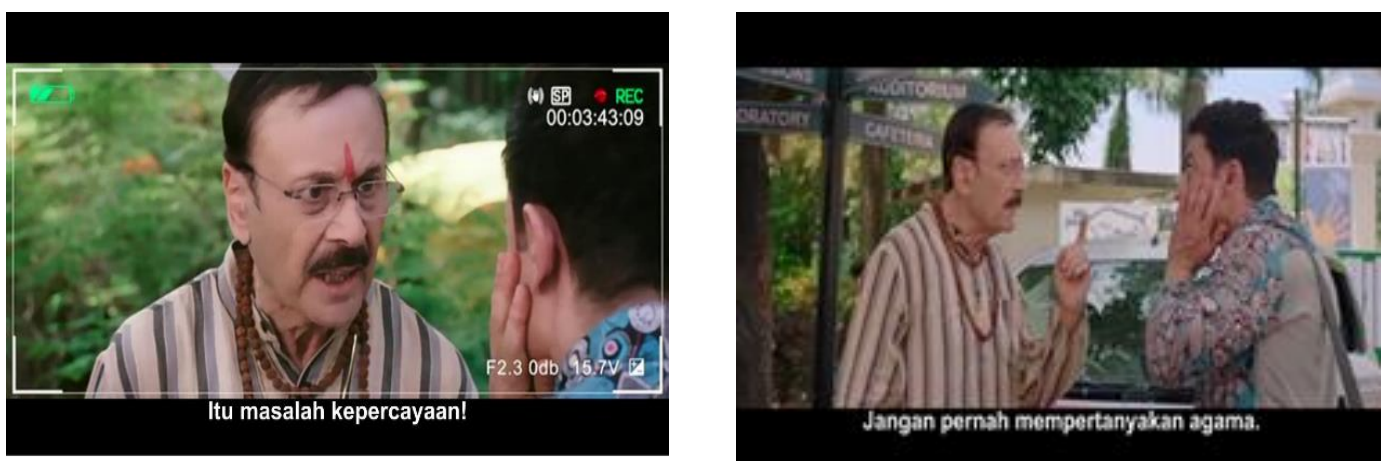

Gambar 3. Pekeey ditampar karena mengkritik batu Siwa

\begin{tabular}{cll}
\hline & Penanda & \multicolumn{1}{c}{ Petanda } \\
\hline Denotasi & "itu masalah kepercayaan, jangan pernah mempertanyakan agama” & $\begin{array}{l}\text { Batu Siwa } \\
\text { Bisnis } \\
\text { Agama }\end{array}$ \\
\hline Konotasi & $\begin{array}{l}\text { Pn 2 } \\
\text { Kepercayaan merupakan hal yang mutlak kebenarannya tidak perlu } \\
\\
\text { dipertanyakan atau diragukan lagi }\end{array}$ \\
\hline Mitos & $\begin{array}{l}\text { Pn3 } \\
\text { Meragukan agama berarti melawan agama menapar sebagai bentuk } \\
\\
\text { membela Tuhan }\end{array}$ \\
\hline
\end{tabular}

Agama adalah otoritas tertinggi yang tidak dapat berubah lagi, dan tidak pernah salah dalam dimensi kehidupan manusia. Oleh karena itu terkadang munculnya tindakan kekerasan mengatasnamakan agama. Tindakan kekerasan tersebut sebagai bentuk penegasan bahwa tidak ada ruang kritik atau pemikiran reduktif. Semua ajaran agama yang telah diajarkan, wajib dilaksanakan oleh masyarakat.

Tindakan penegasan tersebut terkadang memunculkan gerakan keagamaan tersendiri, yang disebut dengan Fundamentalisme. Gerkan Fundamentalisme agama ini terdapat pada beberapa agama, bukan suatu fenomena eksklusif agama tertentu. Gerakan fundamentalisme merupakan suatu gerakan yang menolak pemikiran yang bertentangan dengan pemahaman kelompok agama, terutama terhadap pandangan sekuler, yang hendak menghilangkan sentralitas agama dalam ranah publik. Gerakan Fundamentalisme agama ini sering sekali terjadi dibeberapa negara, seperti India, Sri Lagka dan Turki.

\section{Isu Agama sebagai Akar Ketimpangan Gender}
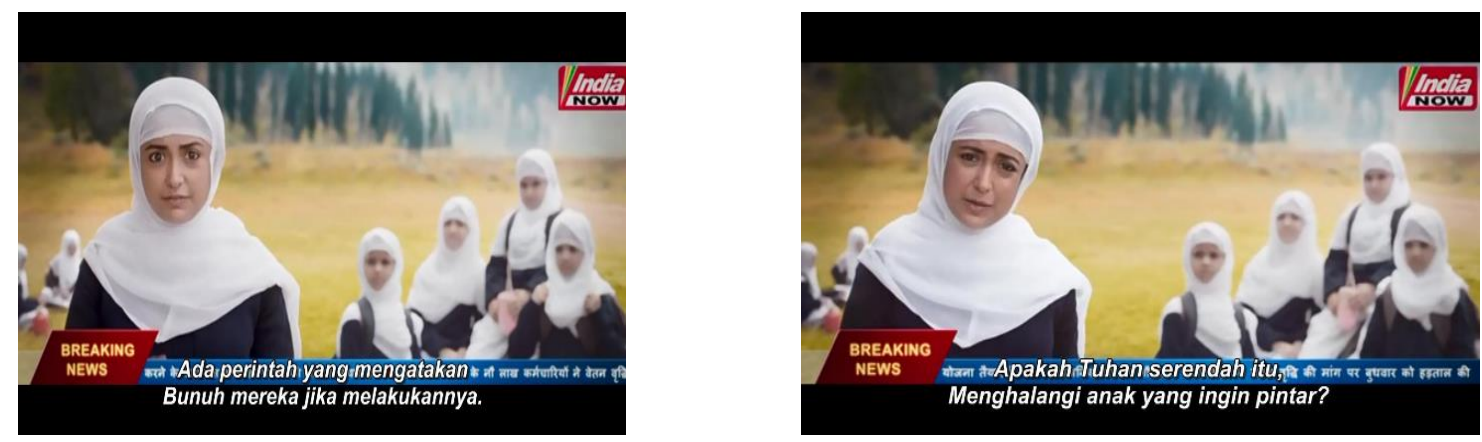

Gambar 4. Diskriminasi perempuan dalam agama 
Wanita Muslim: Ada Perintah yang mengatakan bunuh mereka jika melakukannya, apakah Tuhan serendah itu menghalangi anak pintar?

\begin{tabular}{|c|c|c|}
\hline & Penanda & Petanda \\
\hline Denotasi & $\begin{array}{l}\text { "apakah Tuhan serendah itu, melarang anak ini menjadi } \\
\text { pintar" }\end{array}$ & $\begin{array}{l}\text { Larangan menuntut ilmu } \\
\text { bagi perempuan }\end{array}$ \\
\hline Konotasi & $\begin{array}{c}\text { Pn 2 } \\
\text { Tuhan melarang perempuan menuntut ilmu }\end{array}$ & \\
\hline Mitos & $\begin{array}{l}\text { Pn3 } \\
\begin{array}{c}\text { Melanggar larangan Tuhan berarti menentang Tuhan } \\
\text { maka harus dibunuh }\end{array}\end{array}$ & \\
\hline
\end{tabular}

Gender adalah jenis kelamin bentukan yang dikonstruksi oleh budaya dan adat istiadat (Utaminingsih, 2017). Problem ketidakadilan gender ini merupakan suatu hal yang bersifat sensitif dan tidak mudah untuk dipecahkan. Isu gender ini pun menjadi agenda penting dari semua pihak, karena realitas perbedaan gender yang berimplikasi pada perbedaan status, peran dan tanggung jawab antara laki-laki dan perempuan yang seringkali menimbulkan apa yang disebut dengan ketidakadilan gender atau diskriminasi maupun penindasan (Rohmaniyah, 2009).

Ketidakadilan ini pun terkadag dapat terjadi diberbagai bidang kehidupan, apakah itu dalam wilayah domestik maupun publik seperti dalam bidang politik, ekonomi, kesehatan, keamanan, dan pendidikan. Diskrimnasi tersebut muncul, karena dalam kehidupan masyarakat banyak munculnya pemahaman keagamaan dan budaya yang partiaki.

Agama sering sekali dianggap sebagai akar terjadinya ketimpangan gender. Keterkaitan dengan doktrin agama, atau bahkan seolah-olah mendapat legitimasi teologis. Padahal realitanya tidaklah demikian, melainkan hasil dari konstruksi budaya yang lari dari konsep agama yang sebenarnya. Agama justru mengangkat derajat perempuan dan mendapatkan hak yang sama dalam memperoleh ilmu pengetahuan. Sebagaimana gambaran pada scene di atas, tersebut terlihat perempuan berhijab identik dengan perempuan yang beragama Islam. Perempuan tersebut sedang menyuarakan adanya ajaran agama khususnya Islam yang wrong number. Video tersebut berisi tentang keresahan perempuan Islam di India, yang mendapat ancaman untuk menuntut ilmu dan menjadi pintar. Diskriminasi tersebut karena ada ajaran Agama Islam, yang melarang perempuan untuk belajar dan menjadi pintar. Alasan tersebut dikarenakan Allah marah terhadap perempuan yang bersekolah. Jika ada perempuan yang melanggarnya, maka diperintahkan untuk membunuh perempuan tersebut.

\section{Isu Perampasan Harta atas Nama Agama}
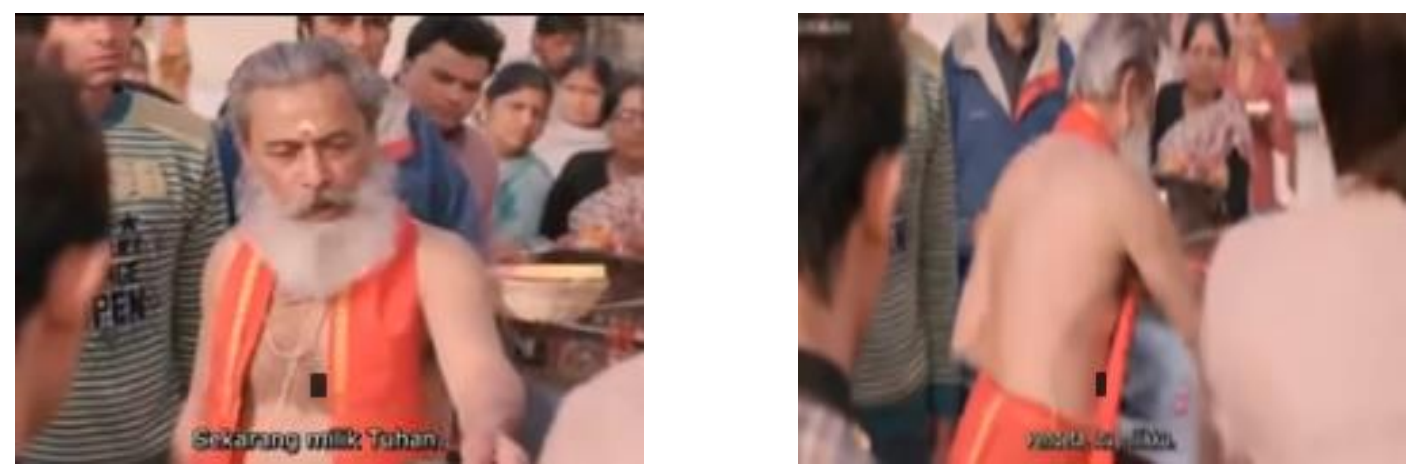

Gambar 5. Merampas harta dengan mengalihkan kepada Tuhan

Jaggu : : Pendeta itu milik ku

Pendeta : Tadinya saat ditangan mu, sekarang milik Tuhan. 


\section{Penanda}

Tadinya saat ditangan mu, sekarang milik Tuhan.
Petanda

Pendeta mengambil uang

\begin{tabular}{ll}
\hline Denotasi & Tadinya saat ditangan mu, sekarang milik Tuhan. \\
\hline Konotasi & Sesuatu yang tidak berada di tangan manusia adalah milik Tuhan \\
\hline Mitos & Memakai nama Tuhan untuk mengambil harta orang lain \\
\hline
\end{tabular}

Demi mendapatkan keuntungan atau keperluan pribadi, terkadang orang-orang memakai nama Tuhan dalam merampas hak orang lain. Sutradara film OMG dan PK memuat tentang pesan dalam kehidupan sosial, yang mana banyak muncul problema kehidupan yang merampas harta seseorang atas nama agama atau Tuhan. Pelaku perampasan tersebut baik itu orang kaya, maupun pemuka agama, memakai agama untuk menyembunyikan kejahatannya dan mengelabui masyarakat awam, supaya masyarakat tidak dapat berkutik dan menerima keadaan yang ada.

\section{Isu Agama sebagai Alat Politik}
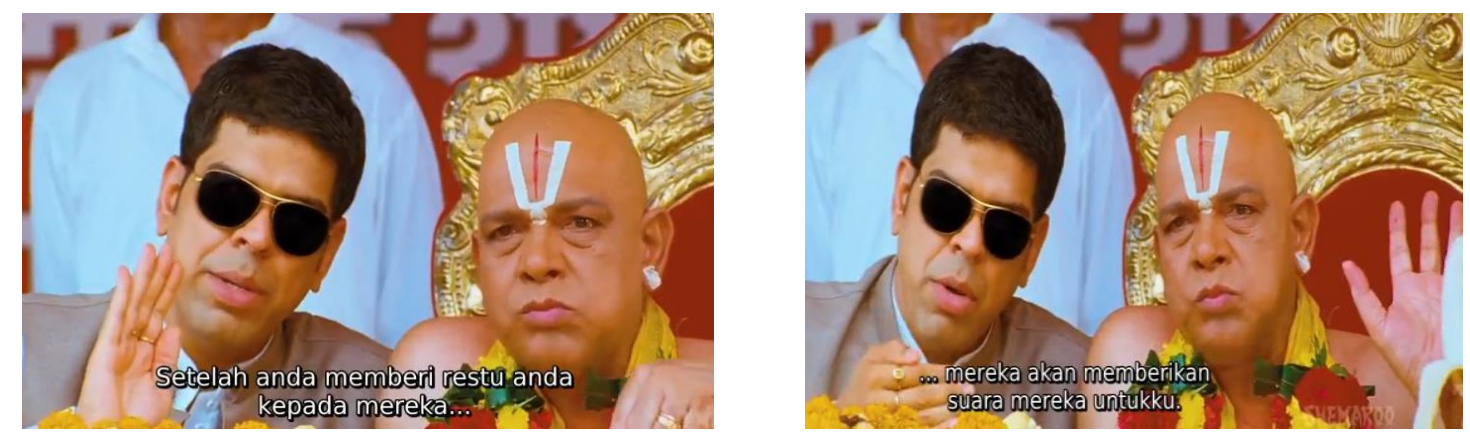

Gambar 6. Pendeta diundang dalam acara kampanye

Mishra : anda memberi restu anda kepada mereka, mereka akan memberikan suara mereka untukku.

\begin{tabular}{ccc}
\hline & $\begin{array}{c}\text { Penanda } \\
\text { anda memberika restu anda kepada mereka, meeka akan } \\
\text { memberikan suara mereka untuk ku }\end{array}$ & $\begin{array}{c}\text { Petanda } \\
\text { Kampanye } \\
\text { dengan pendeta }\end{array}$ \\
\hline Denotasi & anda memberika restu anda kepada mereka, meeka akan \\
& memberikan suara mereka untuk ku \\
\hline Konotasi & Pn 2 \\
& Restu pemuka agama sebagai upan memperoleh suara \\
\hline Pitos & Pn3 \\
& Posisi pemuka agama digunakan sebagai politisi dalam \\
& memperoleh suara terbanyak
\end{tabular}

Sering sekali agama digunakan untuk kepentingan-kepentingan duniawi. Agama merupakan interplay yang paling dominan dalam kehidupan masyarakat. Dalam ranah kehidupan manusia, hampir tidak ada yang absen dari pengaruh agama, termasuk dalam hal berpolitik. Tidak heran jika adanya kegiatan-kegiatan keagamaan yang bernuansa politik, hanya untuk meraih simpati dan suara. Para politisi menyadari bahwa atribut keagamaan, dapat meningkatkan popularitas, dengan cara menyentuh emosional umat (Ruslan, 2014).

Sesuai pada scene di atas memperlihatkan dan menyinggung isu politisasi agama di India. Pada gambar tersebut telihat seorang politisi, mengajak tokoh agama ke dalam urusan politik untuk mengelabui masyarakat, supaya memilih politisi tersebut. Fenomena semacam ini memang terlihat sangat ironis, karena agama dijadikan sebagai kemasan untuk kepentingan politik, bukan menjadi 
dasar menjalankan politik. Politisasi agama tidak hanya terjadi di India saja, akan tetapi juga terdapat di Indonesia. Sebagaimana politik yang terjadi pada tahun 2018-2019, pada pemilihan presiden dan wakil presiden. Kedua kandidat sama-sama menggunakan agama (pemuka agama), untuk memenuhi kepentingannya dalam memenangkan pilkada. Pasangan pertama yang diketuai oleh Jokowidodo, menggandeng seorang kyai atau pemuka agama yakni Kyai Ma'ruf Amin, untuk mengelabui massa. Sedangkan pasangan kedua yang diketuai oleh Prabowo Subianto, mendekati ulama untuk memobilisasi massa.

\section{Strategi Teologi Pembebasan dalam Film Bollywood}

\section{Pelaku Teologi Pembebasan Meyakini Adanya Tuhan}

PK meyakini adanya Tuhan, walaupun masih di dalam kata mencari karena PK yakin hanya ada satu Tuhan yang benar-benar yang maha kuasa. PK mencari Tuhan di setiap agama yang ada di bumi, dan melakukan semua ritual agar Tuhan dapat menghadirkan wujud-Nya, dan mendengarkan doanya dan membantu PK dalam mencari remot kontrol. Khanji meyakini adanya Tuhan lewat perkataannya yang menyatakan "Tuhan yang melakukanya". "Melakukannya" yang dimaksud di sini Tuhan yang telah memberikan bencana alam, mustahil manusia yang membuat bencana sepertti gempa. Pelaku teologi pembebasan agama dalam film Bollywood ini merupakan orang yang mempercayai dan mengimani adanya Tuhan, walaupun pada awal ceritanya kedua aktor dalam film ini belum mengenal Tuhan dan tidak beriman kepada Tuhan.

Pembebasan Tuhan

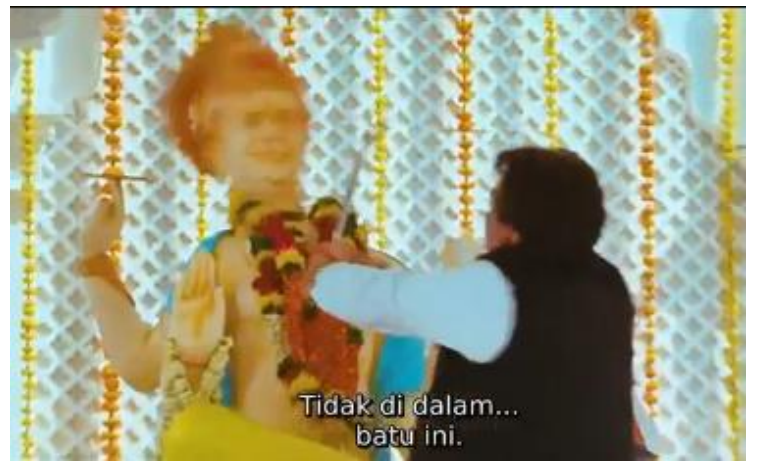

Gambar 7. Khanji menghancurkan patung dewa Khanji

\begin{tabular}{llc}
\hline & \multicolumn{1}{c}{$\begin{array}{c}\text { Penanda } \\
\text { tidak di dalam batu ini }\end{array}$} & \multicolumn{1}{c}{$\begin{array}{c}\text { Petanda } \\
\text { Tuhan tidak di dalam patung }\end{array}$} \\
\hline Denotasi & tidak di dalam batu ini & \\
\hline Konotasi & $\begin{array}{l}\text { Patung sering sekali dijadikan sebagai Tuhan, karena patung alat perantara kepada } \\
\text { Tuhan dan lain sebagainya, sehingga banyak orang memujanya dan menyembahnya. }\end{array}$ \\
& Khanji menghancurkan patung, karena Tuhan tidak berada di dalam patung tesebut. \\
\hline Mitos & $\begin{array}{l}\text { Khanji membebaskan gagasan tentang Tuhan berada dalam sebuah patung dan } \\
\text { membebaskan pemeluk agama dari pemahaman tentang agama dan Tuhan yang } \\
\\
\text { salah. }\end{array}$ \\
\hline
\end{tabular}

Ketergantungan manusia terhadap agama, sudah ditemukan dari zaman purba hingga saat ini. Kehidupan beragama pada dasarnya merupakan kepercayaan terhadap keyakinan adanya kekuatan gaib. Kekuatan tersebut akan memberikan pengaruh pada kehidupan individu maupun masyarakat dan juga pada gejala alam. Kepercayaan tersebutpun akan menimbulkan prilaku seperti berdoa, memuja, dan lain sebagainya (Agus, 2007). Memang pada dasarnya segala sesuatu itu seperti rezeki, hidup, keselamatan adalah ketentuan dan pemberian dari Tuhan. Tuhan memerintahkan manusia 
dalam meminta sesuatu dan menyelesaikan permasalah dengan doa dan diiringi dengan usaha, tidak hanya berpangku kepada doa saja.

Pemahaman masyarakat tentang agama dan Tuhan yang salah ini, sudah berakar dalam kehidupan masyarakat, dan bahkan dijadikan Tuhan sebagai kendaraan dalam menghasilkan uang. Khanji memberitahukan kepada pemeluk agama Tuhan itu Maha Besar dan Maha Kuasa, tidak dibatasi oleh ruang dan waktu, sehingga Tuhan tidak berada dalam patung tersebut bahkan di dalam kuil. Manusia telah menjadikan sifat Tuhan layaknya seperti gambaran manusia dalam jual beli. Oleh karena itu dalam film Bollywood ini memuat pesan yang mana pemahaman terhadap agama atau Tuhan harus diubah atau ditransformasikan kembali.

\section{Pembebasan dari Perpecahan}

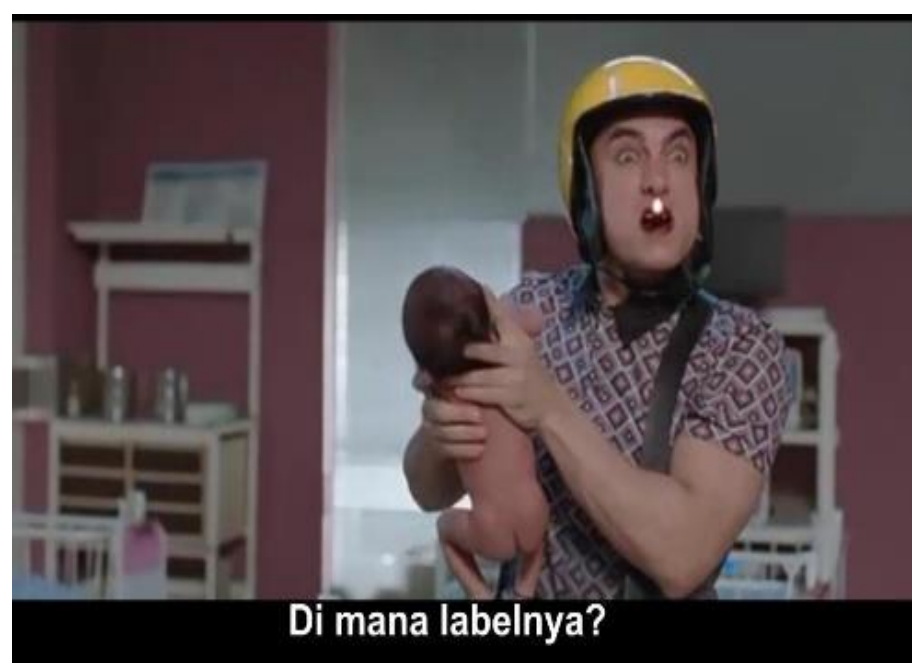

Gambar 8. PK menanyakan label agama pada bayi

\begin{tabular}{ccc}
\hline & Penanda & Petanda \\
\hline Denotasi & $\begin{array}{c}\text { "Tanda agama, bagaimana aku tahu anak ini milik } \\
\text { perusahaan yang mana? Di mana tanda dari Tuhan?" }\end{array}$ & Tanda dari Tuhan \\
\hline Konotasi & Pn 2 \\
& Tanda yang merupakan identitas golongan tertentu & \\
\hline Mitos & Pn3 \\
& $\begin{array}{c}\text { Pencarian identitas manusia yang membuat manusia } \\
\text { berbeda dan terpecah belah }\end{array}$ \\
\hline
\end{tabular}

Agama kerab sekali dikatakan sebagai sumber pertentangan yang dapat mengganggu kesatuan, pembangunan dan keamanan suatu bangsa. Hal tersebut disebabkan beragamnya penganut agama di dunia ini. Pesan dalam film PK, PK dikaim sebagai penganut yang beragama Islam karena Islam selalu diklaim agama yang membawa kekacauan, layaknya teroris yang membuat huru-hara, dan anggapan kebencian tersebut dibentuk oleh manusia sendiri bukan Tuhan. PK mengajak untuk melihat orang bukan dari simbol atau penampilan seseorang. Karena Tuhan menciptakan manusia itu sama, Tuhan tidak menciptakan manusia lebel agama manusia ini beragama, Islam, Hindu, Kristen dan lain sebagainya. Dalam terminologi PK, peran pemuka agama yang melakukan penyelewengan terhadap umat maka akan menyebabkan wrong number" atau "salah sambung" dalam memberikan ajaran agama. Sehingga tidak heran terkadang terjadinya Aksi terorisme merupakan aksi yang berlindung di bawah legitimasi teologis untuk membela Tuhan dan memurnikan doktrin agama, padahal kenyataannya Tuhan tidak perlu dibela, yang hanya membuat manusia kehilangan nyawa. 
Pembebasan dari Kemiskinan

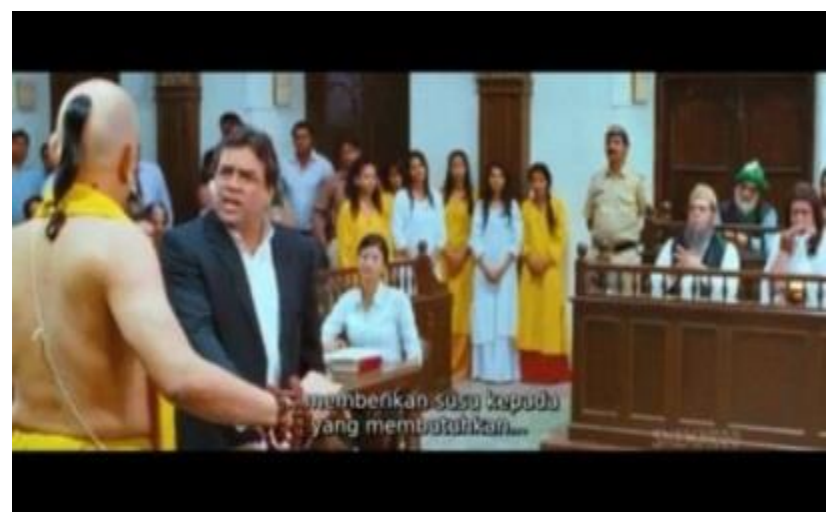

Gambar 9. Ritual pemberian susu

Penanda

Jika setiap orang yang mengunjungi kuil memberikan susu kepada yang membutuhkan, maka mereka akan mendapatkan manfaat

\section{Petanda}

Cerita pengalaman mengunjungi kuil

\begin{tabular}{|c|c|}
\hline Denotasi & $\begin{array}{l}\text { Khanji sedang menjelaskan pengalamannya ke kuil dengan melihat banyaknya } \\
\text { pengemis di luar kuil, dan mengantri memberikan susu kepada simbol dewa yang } \\
\text { terbuang sia-sia Jika setiap orang yang mengunjungi kuil memberikan susu kepada } \\
\text { yang membutuhkan, maka mereka akan mendapatkan manfaat" }\end{array}$ \\
\hline Konotasi & $\begin{array}{l}\text { Memberikan susu kepada yang membutuhkan itu lebih baik dari pada memberikan } \\
\text { kepada patung dan terbuang sia-sia. }\end{array}$ \\
\hline Mitos & $\begin{array}{l}\text { membebaskan penganut dari praktik yang sia-sia dengan memberikan nalarnya } \\
\text { untuk merubah praktik persembahan kepada patung atau batu dengan } \\
\text { memberikannya kepada orang yang memerlukan maka manusia terbebas dari } \\
\text { kemiskinan }\end{array}$ \\
\hline
\end{tabular}

Dalam kehidupan realita sering ditemui praktik keagamaan. Terkadang terdapat ajaran yang tidak masuk akal, yang mana praktik keagamaan tersebut dianggap dapat memberikan jalan keluar atas pemasalahan manusia. Maka Kedua film ini mengajak manusia mencoba lebih mengkritisi praktik agama dari agama masing-masing yang dianggap salah selama ini. Segala praktik keagamaan yang dianggap sia-sia sebaiknya diubah praktik tersebut ke hal yang lebih baik, seperti memberikan susu kepada batu akan lebih baik menyerahkannya kepada orang miskin, dengan demkian masyarakat akan terbebas dari kemiskinan.

\subsection{Mentransformasikan Agama}

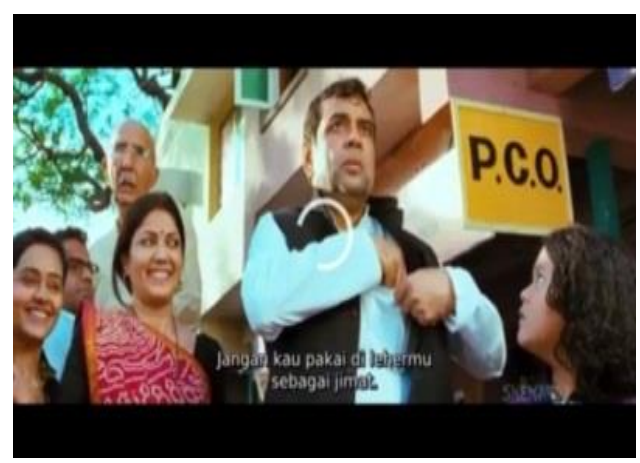

Gambar 10. Melarang memakai jimat 


\begin{tabular}{lc}
\hline & Penanda \\
& Jangan kau pakai di leher mu sebagai jimat $\quad$ Jimat \\
\hline Denotasi & Jangan kau pakai di leher mu sebagai jimat \\
\hline Konotasi & Jimat merupakan barang yang dianggap oleh banyak orang memiliki kekuatan \\
& makanya masyarakat ingin memakainya \\
\hline Mitos & $\begin{array}{l}\text { Larangan memakai benda sebagai jimat akan menggantikan posisi Tuhan } \\
\text { dengan benda jimat tersebut }\end{array}$ \\
\hline
\end{tabular}

Scene dan dialog di atas menggambarkan realitas sosial keagamaan manusia, menjadikan patung sebagai Tuhan, kalung sebagai jimat. Selain itu manusia mencari Tuhan jika ada perlunya, dan manusia menyembah Tuhan bukan dilandasi karena cinta akan tetapi karena ketakutan. Hingga masyarakat sukarela melakukan apapun, memberikan persembahan apapun demi memenuhi kepentingannya. Manusia telah menjadikan sifat Tuhan layaknya seperti gambaran manusia dalam jual beli. Oleh karena itu dalam film Bollywood ini memuat pesan yang mana pemahaman terhadap agama harus diubah atau ditransformasikan kembali yang bahwa janganlah menjadikan simbol sebagai Tuhan, menjadikan benda sebagai jimat karena semua itu sama dengan menggantikan posisi Tuhan sebanarnya dengan benda tersebut.

\section{Kesimpulan}

Film PEEKEY dan OH MY GOD mengangkat isu-isu agama yang menunjukkan bahwa agama terlahir dari harapan dan ketakutan manusia, kemudian menggambarkan agama yang membuat konflik sehingga manusia saling bunuh-membunuh, dan digambarkan sebagai bentuk keterasingan dan penghalang bagi manusia untuk melakukan kreativitasnya sebagai mahluk yang bebas dan menjadikan manusia menjadi mahluk individualis dalam kelas-kelas sosial. Eksploitasi politik dalam agama yang menunjukkan bahwa agama hanya dijadikan sebagai instrumen untuk memapankan kekuasaan. Film bollywood ini mencoba mentransformasikan agama dengan membebaskan manusia dari pemahaman Tuhan yang bersifat manusiawi, agama dari bisnis, ritual yang mubazir, dan bendabenda yang dapat menggantikan posisi Tuhan, masyarakat dari sistem agama yang menindas, pemerasan dan kemanusiaanlah yang patut dibela karena Tuhan tidak perlu dibela.

\section{Referensi}

Agus, B. (2007). Agama dalam Kehidupan Manusia. Jakarta: Raja Grafindo.

Aryanto, W. (2009). Panduan Praktisi Public Relation. Jakarta: Elex Media Komputindo.

Hoed, B. H. (2008). Semiotik dan Dinamika Sosial Budaya. Depok: Komunitas Bambu.

Kurniawan. (2001). Semiologi Roland Barthes. Magelang: Yayasan Indonesiatera.

Kwant. (1975). Manusia dan Kritik. Yogyakarta: Kanisius.

Lantowa, J., Marahayu, N. M., \& Khairussibyan, M. (2017). Semiotika: Teori, Metode, dan Penerapannya dalam Penelitian Sastra. Yogyakarta: Budi Utama.

Moleong, L. J. (2019). Metodologi penelitian kualitatif.

Narodangin, J. N. (2019). Semiotika Roland Barthes.

Nitiprawiro, F. W. (2000). Teologi Pembebasan (Sejarah, Metode, Praksis, dan Isinya). Yogyakarta: Lkis Printing Cemerlang.

Nitiprawiro, F. W. (2010). Teologi Pembebasan: Sejarah, Metode, Praksis, dan Isinya. LKIS PELANGI AKSARA.

Rahman, M. T. (2018). Pengantar filsafat sosial.

Ridwan, M. (2016). Agama antara Cita dan Kritik. Fikrah: Jurnal Ilmu Aqidah Dan Studi Keagamaan, 4(1), 161.

Rohmaniyah, I. (2009). Gender dan konstruksi Perempuan dalam Agama. Jurnal Studi Ilmu-Ilmu Al-Qur'an Dan Hadis, 10(2), 209.

Ruslan, I. (2014). Paradigma Politisasi Agama (Upaya Reposisi Agama dalam Wilaya Publik). Jurnal Madania, 18(2), 162.

Susanto, A. S. (1977). Komunikasi dalam Teori dan Praktek. Bandung: Binacipta.

Suseno, F. M. (1999). Pemikiran Karl Marx (dari Sosialisme Utopis ke Perselisihan Revisionisme). Jakarta: Gramedia Pustaka.

Tazid, A. (2017). Toko, Konsep dan Kata Kunci Teori Post Modern. Yogyakarta: Budi Utama. 
Utaminingsih, A. (2017). Gender dan Wanita Karir. Jakarta: UB Press.

Vera, N. (2014). Semiotika dalam Riset Komunikasi. Bogor: Ghalia Indonesia.

Wibisono, M. Y. (2020). Sosiologi Agama.

wikipedia. (2020). Teologi pembebasan.

Willya, E. (2012). Senarai Penelitian, Islam kontenporer Tinjauan Multikultural. Yogyakarta: Deepublish.

Yudiono. (2009). Pengkajian Kritik Sastra Indonesia. Jakarta: Grasindo.

(C) 2021 by the authors. Submitted for possible open access publication under the terms and conditions of the Creative Commons Attribution (CC BY SA) license (https://creativecommons.org/licenses/by-sa/3.0/). 